MLIVER, A. H., \& NIELSON, H. C. Effects of electroconvulsive shock and grid shock on open field behavior. Journal of Comparative \& Physiological Psychology, 1966, 62, 102-107.

NIELSON, H. C. Evidence that electroconvulsive shock alters memory retrieval rather than memory consolidation. Experimental Neurology, 1968, 20, 3-20.

NIELSON, H. C., JUSTESEN, D. R., \& PORTER, P. B. Effects of anticonvulsant drugs upon patterns of seizure discharge and brain thresholds: Some implications for memory mechanisms. Psychological Reports, 1969, 23, 843-850.

\section{NOTES}

1. This study was supported by 8200 Research Funds from the U.S. Veterans Administration. Mrs. Kay Wahl and Mr. Harold Bowen of the V. A. Hospital's medical illustration service are warmly acknowledged for their preparation of the figures.

2. Present address: Department of Psychology, University of Utah, Salt Lake City, Utah 84112.

\title{
Magnesium pemoline: Different effects with different subject stocks'
}

\author{
JOHN A. CORSON, McGill University, \\ Montreal 110, Canada
}

Twenty-four Sprague-Dawley and 24 Long-Evans rats were tested in a situation requiring a pole-climbing response. Half of the members of each stock were injected with magnesium pemoline and half with vehicle. Magnesium pemoline had a transient interfering effect on the learning of the Sprague-Dawley animals and prolonged the extinction of the Long-Evans animals. These results suggest that the eventual description of the behavioral effects of magnesium pemoline will be in terms of a matrix involving variations in stock of S and type of task.

Magnesium pemoline (MP) has been reported to stimulate brain ribonucleic acid polymerase activity (Glasky \& Simon, 1966) and to improve the performance of a shock-motivated response by rats (Plotnikoff, 1966). There has been a controversy over the existence of the biochemical effect of MP (Morris, Aghajanian, \& Bloom, 1967; Stein \& Yellin, 1967; Brink \& Stein, 1967), which is confused by procedural differences. There have also been controversies concerning the behavioral effects of MP. At the human level, the controversy has concerned both the existence and explanation of the effects of MP (Smith, 1967), while at the animal level, the problem has been primarily one of explanation. At the animal level, the explanation proposed by Plotnikoff (1966) was in terms of enhancement of learning and memory, while other workers (Frey \& Polidora, 1967; Beach \& Kimble, 1967) have proposed that MP produced behavioral effects by reducing the tendency to freeze or, similarly, by energizing or stimulating the S. Between these general classes of explanation, it seems that a much stronger case can be made for MP having a stimulating effect than for its having the effect of enhancing learning and memory. For example, recent reports show that MP produces increased motor activity (Boitano \& Boitano, 1967) and a deficit in passive-avoidance learning, where animals are required to inhibit a response (Gurowitz, Lubar, Ain, \& Gross, 1967). However, the picture at this point is confused by differences among the various reports in such variables as stock of $S$ and the type of task used to assess the effect of MP.

We recently reported (Corson, 1967) a series of studies of the behavioral effect of MP on the performance of rats in a variety of tasks. In several of these studies we ran our Ss through a series of shock-motivated tasks ranging from simple escape to pattern discrimination. This series of tasks was used

\section{Table 1}

Effect of Magnesium Pemoline on Leaming and Extinction Performance of Naive Long-Evans and Sprague-Dawley Rats in a Shock-Motivated Pole-Climbing Task

\begin{tabular}{|c|c|c|c|c|c|c|c|c|c|c|}
\hline \multirow[b]{2}{*}{ Measure } & \multicolumn{4}{|c|}{ Long-Evans } & \multirow[b]{2}{*}{$\mathrm{p}^{*}$} & \multicolumn{4}{|c|}{ Sprague-Dawley } & \multirow[b]{2}{*}{$\mathrm{p}^{*}$} \\
\hline & $\begin{array}{l}\text { Experi } \\
\text { Median }\end{array}$ & $\begin{array}{c}\text { nental } \\
\text { Range }\end{array}$ & $\begin{array}{r}\text { Contr } \\
\text { Median }\end{array}$ & $\begin{array}{l}\text { rol } \\
\text { Range }\end{array}$ & & $\begin{array}{l}\text { Experir } \\
\text { Median }\end{array}$ & $\begin{array}{l}\text { imental } \\
\text { Range }\end{array}$ & $\begin{array}{r}\text { Cont } \\
\text { Median }\end{array}$ & $\begin{array}{l}\text { trol } \\
\text { Range }\end{array}$ & \\
\hline $\begin{array}{l}\text { Number of trials } \\
\text { to first climb }\end{array}$ & Is 2 & $1-3$ & 1.5 & $1-7$ & $>0.1$ & 6 & $1-20+$ & 2 & $1-10$ & $<.05$ \\
\hline $\begin{array}{l}\text { Number of climbs } \\
\text { on Day } 1\end{array}$ & bs 9 & $7-10$ & 9.5 & $4-10$ & $>0.1$ & 4.5 & $0-10$ & 8 & $1-9$ & $<0.1$ \\
\hline $\begin{array}{l}\text { Mean hold durati } \\
\text { of successful } \\
\text { climbs on Day } 1\end{array}$ & 22.9 & $5.5-34.4$ & 24.2 & $4.2-42.2$ & $>0.1$ & 10.0 & $2.0-34.7$ & 18.7 & $3.0-33.6$ & $>0.1$ \\
\hline $\begin{array}{l}\text { Number of climbs } \\
\text { on Day } 2\end{array}$ & bs 10 & $10-10$ & 10 & $7-10$ & $>0.1$ & 8.5 & $0-10$ & 10 & $7-10$ & $>0.1$ \\
\hline $\begin{array}{l}\text { Mean hold duratio } \\
\text { of successful } \\
\text { climbs on Day } 2\end{array}$ & 29.1 & $13.5-44.5$ & 528.7 & $60-49.9$ & $>0.1$ & 13.2 & 4.9-32.5 & 30.1 & $4.9-44.9$ & $>0.1$ \\
\hline $\begin{array}{l}\text { Number of climbs } \\
\text { on extinction } \\
\text { Day } 1\end{array}$ & 9.5 & $4-10$ & 4 & $0-10$ & $<0.2$ & 2.5 & $0-10$ & 0 & $0-10$ & $>0.1$ \\
\hline $\begin{array}{l}\text { Number of climbs } \\
\text { on extinction } \\
\text { Day } 2\end{array}$ & 6.5 & $0-10$ & 0 & $0-10$ & $<.05$ & 0 & $0-10$ & 0 & $0-10$ & $>0.1$ \\
\hline
\end{tabular}

*The $p$ values were calculated with the two-tailed Mann-Whitney U test.

Two experimental Sprague-Dawley $S$ s made no responses during learning or extinction, but a separate analysis with these animals omitred did not change the significance levels shown here. 
All of these Ss were males and all were obtained from the Canadian Breeding Laboratories. They weighed between 200 and $250 \mathrm{~g}$ at the start of the experiment.

The apparatus consisted of a plywood box, 9 in. square and $17 \mathrm{in}$. high, painted flat grey, with a Plexiglas top for delivery of the CS and a grid floor for delivery of the shock. Suspended from the top of the apparatus was a $3 / 4$-in. dowel with grooves cut at $1 / 2$-in. intervals. Shock, at $350 \mathrm{~V}$ and $1.8 \mathrm{~mA}$, was turned on simultaneously with a buzzer, at $60 \mathrm{cps}$ and $80 \mathrm{~dB}$, and both were left on for $30 \mathrm{sec}$ or until $\mathrm{S}$ climbed clear of the grid. The intertrial interval was $2 \mathrm{~min}$. Ten learning trials were given each day for 2 days, and following this, 2 days of extinction were given, also with 10 trials per day. The measures taken on this task were number of trials to the first climb, latency of each climb, number of climbs, and the length of time the animal held onto the pole on each climb (hold duration). Since the animals appeared to release their grip on the pole because of fatigue, the mean duration of these "holds" during the learning trials should be a crude index of physical strength or endurance.

A single dose of $20 \mathrm{mg} / \mathrm{kg}$ was used for the purposes of this study. This dose has been well established (Plotnikoff, 1966; Beach \& Kimble, 1967) as being within the effective range for producing behavioral effects, and this was the only dose level used in a subsequent study by Frey \& Polidora (1967) which showed clear behavioral effects on Sprague-Dawley rats.

Twelve Ss of each stock were given intraperitoneal injections of $20 \mathrm{mg} / \mathrm{kg}$ of MP $30 \mathrm{~min}$ before the start of the initial training session and before the start of each subsequent session. Twelve control Ss of each stock were similarly injected with an equal volume of gum tragacanth vehicle.

\section{RESULTS AND DISCUSSION}

Due to nonhomogeneity and nonnormality of the data, the results were analyzed with the Mann-Whitney $U$ test. The results, presented in Table 1 , show similar trends to those found with the animals with prior experience with shock-motivated tasks (Corson, 1967). MP prolonged the extinction of the Long-Evans Ss and had a transient interfering effect on the learning of the Sprague-Dawley Ss. (These results differ from those of our earlier study in that here there is noeffect of MP on learning of the Long-Evans Ss. This difference may be due to the exclusion of transfer and interference effects from the present study.) The transience of the difference in the Sprague-Dawley sample (a rather large difference in the number of trials to the first climb, a marginally significant difference in the total number of climbs, and a nonsignificant difference in the number of climbs on Day 2) suggests that the effects on this sample are limited to the early stages of learning in this situation. The fact that there were no differences in any of the hold duration measures suggests that differences in physical strength or endurance are not at the basis of these effects.

While the prolonged extinction found with Long-Evans Ss could be seen as the result of an energizing effect of MP, it would be difficult to explain the lack of an energizing effect in learning of this task or in performance in the other situations used in the earlier study (Corson, 1967). The disruption of pole-climbing learning found with Sprague-Dawley Ss could similarly be discussed in terms of an energizing effect of MP which somehow handicapped these Ss in this situation; however, this effect must be seen as restricted to learning in this situation, and not to extinction.

The explanation of the effect of MP in terms of modification of the tendency to freeze is faced with similar problems. While there were no significant differences in mean escape latency on either of the 2 days of learning, examination of the raw data suggests that one could make a case for an effect of MP on freezing, at least in the Long-Evans Ss (for example, the number of climbs made in less than $2 \mathrm{sec}$ on the first day of leaming is $\mathbf{4 8}$ for the experimental animals and only 21 for the controls). However, there were no such trends in the performance of the Sprague-Dawley Ss.

The evidence indicates that there is, at present, no adequate explanation of the effects of MP on behavior. It now seems that even a simple description of the behavioral effect of MP at the level of the rat will be possible only after assessment of the interactions of many variables. It is likely that this description will be in terms of a matrix involving variations in stock of $S$ and type of task (as suggested by our work), as well as in such relatively minor features as sensory modality of important cues, as suggested by the work of Chase \& Rescorla (1968).

\section{REFERENCES}

BEACH, G., \& KIMBLE, D. P. Activity and responsivity in rats after magnesium pemoline injections. Science, 1967, 155, 698-701.

BOITANO, J. J., \& BOITANO, J. C. Magnesium pemoline: Enhancement of spontancous motor activity. Psychonomic Science, 1967, 9, 295-296.

BRINK, J. J., \& STEIN, D. G. Pemoline levels in brain: Enhancement by dimethyl sulfoxide. Science, 1967, 158, 1479-1 80 .

CHASE, T. C., \& RESCORLA R. A. The effect of magnesium pemoline on earning an active avoidance-passive avoidanc: discrimination. Psychonomic Science, 1968, 10, 87-88.

CORSON, J. A. Studies of the effects of manipulation of brain metabolism on learning. I. Vitamin B12. II. Magnesium pemoline (Cylert). III. Malononitrile Dimer (U9189). IV. Anodal polarization. 6571 st Aeromedical Research Laboratory Technical Report ARL-TR-67-18, Holloman Air Force Base, New Mexico, 1967, 1-48.

FREY, P. W., \& POLIDORA, V. J. Magnesium pemoline: Effect on avoidance conditioning in rats. Science, 1967, 155, 1281-1282.

GLASKY, A. I., \& SIMON, L. N., Magnesium pemoline: Enhancement of brain RNA polymerases. Science, 1966, 151, 702-703.

GUROWITZ, E. M., LUBAR, J. F., AIN, B. R., \& GROSS, D. A. Disruption of passive avoidance learning by magnesium pemoline. Psychonomic Science, 1967, 8, 19-20.

MORRIS, N. R., AGHAJANIAN, G. K., \& BLOOM, F. E. Magnesium pemoline: Failure to effect in vivo synthesis of brain RNA. Science, $1967,155,1125-1126$

PLOTNIKOFF, N. Magnesium pemoline: Enhancement of learning and memory of a conditioned avoidance response. Science, 1966 , 151, 703-704.

SMITH, R. G. Magnesium pemoline: Lack of facilitation in human learning, memory and performance tests. Science, 1967, 155, 603-605.

STEIN, H. H., \& YELLIN, T. O. Pemoline and magnesium hydroxide: Lack of effect on RNA and protein synthesis. Science, 1967, 157, 96-97.

NOTE

1. This research was supported by the Medical Research Council of Canada, Grant MA 1746, and by a Research Career Award from the Canadian Association for Retarded Children. I thank Susanna Kertesz and Adrienne Spiegal for their assistance and R. A. Cleghorn and K. F. Ley for their criticisms of the manuscript. 